\title{
KATHERINE MANTHORNE
}

II

Comisión Corográfica da

Colômbia: um mapa estendido

do corpo político

Tradução: Vinícius de Oliveira Godoy

\section{RESUMO}

O artigo analisa a obra artística produzida pela Comisión Corográfica que visitou a Colômbia na década de 1850. Organizada pelo governo para criar um catálogo visual descritivo das regiões e das povoações do seu território, quando estruturavam as divisões administrativas da jovem república. $O$ chefe deste projeto, foi o geógrafo Agustín Codazzi, e com ele trabalharam três artistas: Carmelo Fernández, Enrique Price e Manuel Maria Paz. A obra registra os tipos da população, destacando as diferenças em função da sua origem sócio-econômica e regional, e a paisagem com o sentido de um catálogo visual da diversidade geográfica do país, e só foi publicada parcialmente, na sua parte cartográfica; entretanto, a iconografia apenas tem sido divulgada.

PALAVRAS-CHAVE

comissão corográfica; comisión corográfica; desenhos; tipos populares; paisagem; Agustín Codazzi. 


\section{COMISIÓN' COROGRÁFICA DA COLÔMBIA: UM MAPA ESTENDIDO DO CORPO POLÍTICO}

Foi mantido o original Comisión e não a sua tradução em língua portuguesa (Comissão) já que, no texto em inglês, a palavra também se encontra em língua espanhola, colocando-se 0 termo em itálico, assim como outros termos que no texto original também estão em língua espanhola. (N.T.).

Jorge Luis Borges, "Do rigor na ciência”. Suárez Miranda: Viajes de varones prudentes, livro quarto, cap. XIV, Lérida, I658. Obras Completas, Vol. II, p. 223.

Guillermo Hernandez de Alba, Acuarelas de la Comisión Corografica, Colombia, 1850-1859. Bogotá: Litografía Arco, 1986. Essa é a publicação mais completa sobre a expedição com pranchas coloridas de todas as imagens, mas carente de análises da história da arte.
“...Naquele Império, a arte da cartografia atingiu uma tal perfeição que o mapa de uma só Província ocupava toda uma Cidade, e o mapa do Império, toda uma Província. Com o tempo, esses mapas desmedidos não satisfizeram e os colégios de cartógrafos levantaram um mapa do Império que tinha o tamanho do Império e coincidia ponto por ponto com ele. Menos apegadas ao estudo da cartografia, as gerações seguintes entenderam que esse extenso mapa era inútil e não sem impiedade o entregaram às inclemências do Sol e dos invernos. Nos desertos do Oeste subsistem despedaçadas ruínas do mapa, habitadas por animais e por mendigos. Em todo o país não resta outra relíquia das disciplinas geográficas." Jorge Luis Borges, "Museum"

\section{Introdução}

Em 1850 a República da Colômbia deu um passo sem precedentes com o estabelecimento de uma Comisión Corográfica, um grupo expedicionário composto por geógrafos, naturalistas, escritores e artistas. Mapeando a diversidade cultural e étnica das regiões dentro de um terreno multidimensional, a meta foi a definição da identidade Colombiana. Sob a liderança do geógrafo Agustín Codazzi, o projeto de dez anos fez uma significante contribuição para a cultura visual da exploração científica na forma de um álbum com 152 aquarelas. Estas constituem uma importante tipologia pictórica das pessoas e do meio ambiente, criado por três artistas sucessivamente: Carmelo Fernández (I850-5I), Enrique Price (I85 I) e Manuel María Paz (I852- I859). Um dos mais extensos registros deste tipo na América do Sul, o álbum tem, contudo, que submeter-se a uma análise da história da arte ${ }^{3}$. Quando esta expedição é, de algum modo, mencionada nos escritos sobre a arte latino-americana do século dezenove, um ou dois estudos das mesmas figuras de sempre, feitas por Fernándes em seu primeiro ano, são discutidas, como se elas pudessem representar o trabalho de três artistas realizados ao longo de nove anos. Meu objetivo aqui é diferenciar mais claramente as mãos dos artistas, realizando 
leituras mais acercadas, através de uma seleção com um corte transversal de algumas imagens, contextualizando-as em termos de arte expedicionária e da história colombiana daquele momento. A meta deste ensaio é situar as aquarelas de suas terras e corpos, habitados na intersecção de dois campos contíguos - cartografia e arte - mutuamente animados pela nova agenda nacionalista.

Nosso ponto de partida é Bogotá, a capital, lugar de poder e autoridade, já que a Comisión foi em última instância um projeto metropolitano. Apesar da equipe da comissão passar quase todos os seus dez anos pesquisando as regiões remotas ou departamentos, seu centro foi a capital distrital e o presidente que a criou por decreto apenas um ano depois de tomar posse.

A eleição do General José Hilario López como Presidente, em I849, marcou uma mudança para a Colômbia, tanto econômica quanto politicamente. O capitalismo começou a substituir a velha estrutura colonial e as diferenças ideológicas entre os partidos políticos estabelecidos obscureceu a ênfase anterior no personalismo que caracterizava o caudilho fortemente armado. Em I 850 a administração López efetivou duas mudanças de conseqüências duradouras: aboliu a escravidão e instituiu uma nova política de distribuição de terras. Com a intenção de permitir aos proprietários de terras o acesso a mais terras, o programa de reforma agrária levantou as restrições sobre a venda das terras de resguardo; como resultado, os indígenas foram deslocados de seus locais de origem e movidos para as cidades, onde eles proveram a mão-de-obra excedente. Simultaneamente, López dividiu o país em divisões administrativas que sobrevivem até os dias de hoje: a capital distrital de Santa Fé de Bogotá e trinta e dois departamentos. Ele então criou a Comisión Corográfica para inspecionar aquelas pessoas e aquelas terras e estabelecer um inventário visual da nação. Mas qual visão da República emergiu ao final deste projeto? E para que fim?

\section{Codazzi como líder da comissão corográfica}

A expedição foi liderada pelo italiano Codazzi, cuja silhueta aparece em uma aquarela de Fernández, Acampamento da Comision, Yarumito (fig. I). Na esquerda e na direita da cena os membros da expedição tomam seus acentos, repousam em redes, preparam a refeição na fogueira do acampamento ou descansam. Esses homens são todos de pele escura, vestidos com os trajes dos campesinos e engajados em tarefas servis. Localizado em uma pequena elevação em uma clareira, no centro, erguidos em perfil, estão dois Euro-americanos, um deles identificado como sendo Codazzi pelo telescópio que ele mantém em seu olho. A cena diante de nós não tem pontos de referência imediatamente identificados; poderia representar muitos lugares na rota que Codazzi seguiria ao longo dos próximos nove anos. Pretendemos, portanto, interpretar essas imagens não em termos das especificidades, de um local em particular, mas ao 


แ

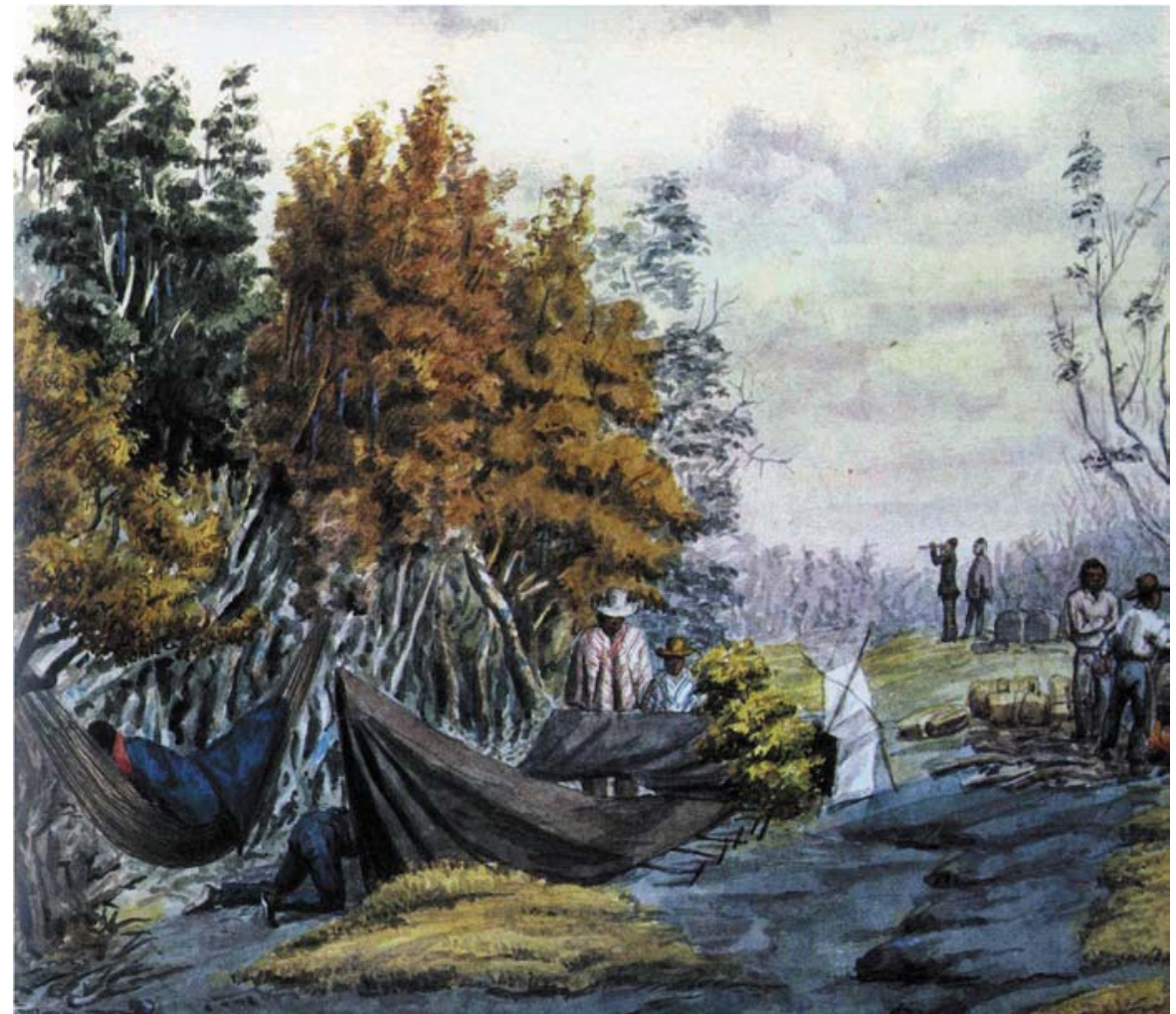

Fig. I - Carmelo Fernández, Encampment of the Comisión, Yarumito(detalhe), I850. Biblioteca Nacional, Bogotá, Colombia.

contrário, como um indicador da amplitude das ambições do projeto. A configuração do homem na paisagem é eloqüente, com os indígenas e mestizos engajados em trabalhos servis enquanto o olhar euro-americano é geograficamente posto na distância, com um ar de autoridade. Essa imagem nos traz a mente a frase: "mestre de todos, ele supervisiona", um indicador que no ato de supervisionar e mapear o terreno ele está tomando posse do mesmo em nome de seus patrões, a classe dominante crioula.

Codazzi foi de fato confortavelmente abrigado nos altos escalões da sociedade em Bogotá. Ele estava inteiramente integrado em sua cidade de adoção, como o viajante estadunidense Isaac Holton notou em sua visita:

Isaac F. Holton, New Granada: Twenty Months in the Andes. NY: Harper \& Bros, 1857, p. 172.
"Em nenhuma família em Bogotá estive eu hospedado com maior prazer do que na do Coronel Codazzi, o qual vive três ruas acima da Catedral. O coronel é italiano, e sua senhora uma venezuelana, mas o mais jovem de seus numerosos e inteligentes filhos é bogotano." 4 
Antes de trabalhar em Bogotá, Codazzi conduziu uma pesquisa maior na vizinha Venezuela. Treinado na Itália em geografia clássica, ele trabalhou com métodos tradicionais ligados a mapas e elaboração de retratos. Em sua tradição ptolomaica, ele contratou três sucessivos artistas/colaboradores, aos quais agora nos voltamos.

\section{Os artistas}

Antigo diretor da primeira escola de Belas Artes colombiana, Manuel María Paz ( I820-1902) proveu o ponto de partida mais útil para nossa discussão sobre os artistas, por ter servido por mais tempo - sete anos - enquanto cada um dos outros serviu por apenas um ano. Apenas ele era nascido na Venezuela, no departamento de Cauca. Muitas de suas aquarelas traçam uma dualidade, pretendem representar habitantes típicos da região, de um particular mix racial e de classe. Sua descrição dos Indio de Puracé (fig. 2) transmite um senso de dignidade e individualidade mais pronunciada do que encontramos nos tratamentos de nativos feitos por artistas estrangeiros. Para mim, seu estilo não acadêmico carrega o mesmo fascínio do pintor indígena estadunidense George Catlin. Ele foi um soldado, pintor e cartógrafo. A técnica de $\mathrm{Paz}$, por essa razão, permite o acesso a seu pessoal amálgama das demandas da pintura e da criação de mapas, evidente também nas paisagens que ele produziu na expedição. ${ }^{5}$

Carmelo Fernández (1810-1887) iniciou o trabalho artístico na Comisión, em I850-1851. Seu mandato e o de seus colegas artistas foi minuciosamente descrito em seu contrato: ele foi para ilustrar as descrições escritas por Ancizar "com gravuras de paisagens singulares, tipos de tribos e raças, cenas mostrando costumes característicos do povo, antigos monumentos já conhecidos ou descobertos pelos membros da Comissão." Como sobrinho de Antonio Paez - líder revolucionário e, por fim, presidente da

Fig. 2 -Manuel María Paz, Indios de Puracé, 1853. Biblioteca Nacional, Bogotá, Colombia.

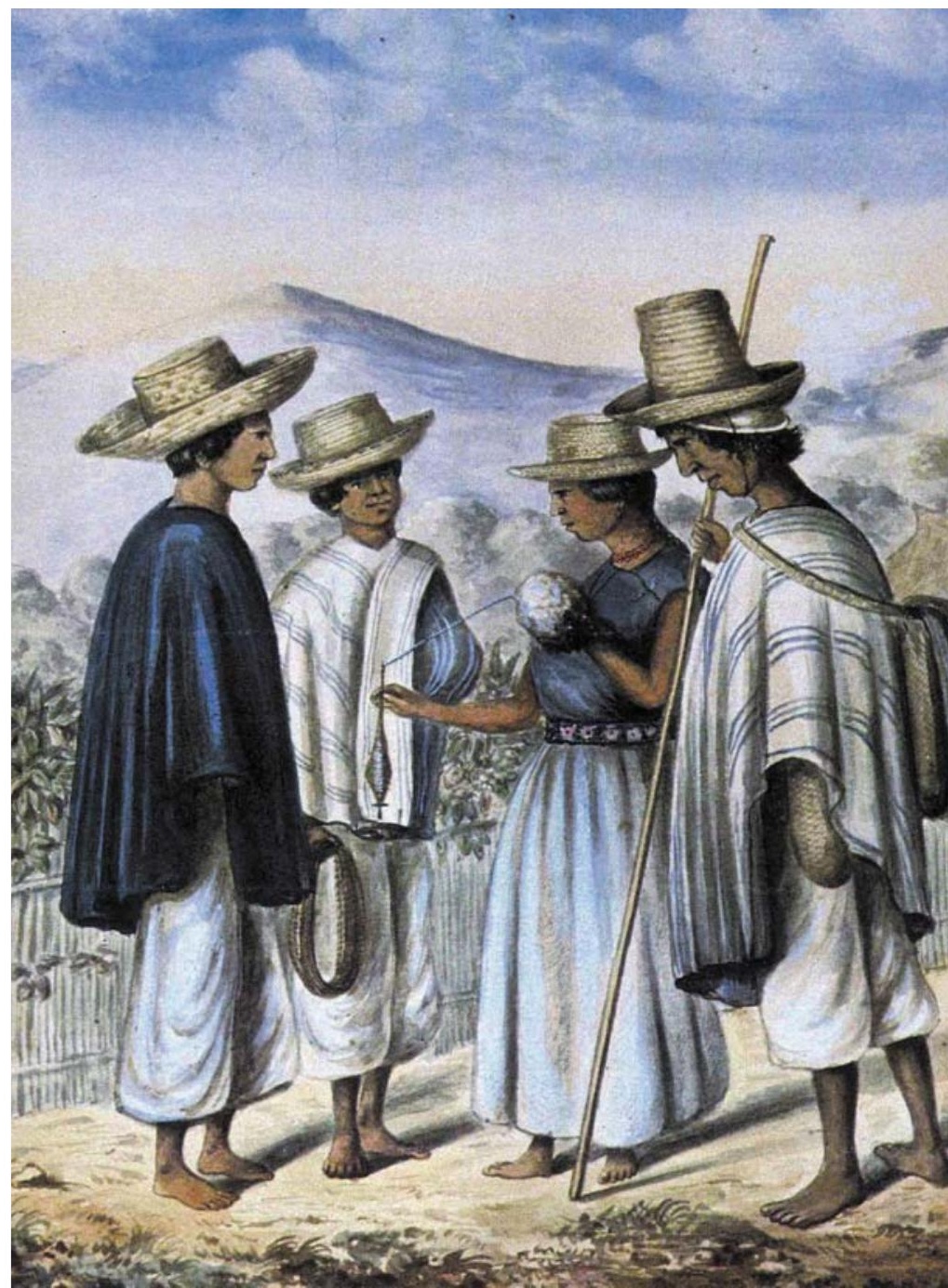


Mary Louise Pratt, Imperial Eyes, p.176; este livro traz importantes insights dentro das questões que ela trata com 0 termo de "transculturação". vizinha Venezuela - Fernández teve um interesse particular na representação das pessoas e das terras livres e independentes da República; além disso, suas habilidades artísticas eram ajustadas à tarefa de representar em conformidade com tal cidadania.

Ao final do ano de I85I, Fernández saiu da Comisión, deixando o estudo da província de Antioquia ao seu sucessor, Enrique Price (1819-1863). O inglês Price desembarcou em Bogotá em I 84I, ligado a uma firma de negócios britânica. Homem culto, Price fundou a Sociedad Filarmónica, a primeira da Colombia. Ele estudou pintura, lecionou e compôs música. Trabalhando com a Comisión em I852, ele trouxe uma visão ampliada desta província: lugares importantes, a configuração da terra e mesmo o modo no qual os vinhedos cresciam junto às árvores. Tão bem realizadas foram essas visões da natureza que seu trabalho é visto como o fundador da pintura de paisagem colombiana.

\section{Patrocínio da Elite Crioula}

Esses artistas, como a própria expedição, encontraram seu apoio e patrocínio na classe dominante crioula. "As elites - com o poder de construir novas hegemonias na América - foram desafiadas a imaginar muitas coisas que não existiam", como Mary Louis Pratt escreveu, "incluindo a si mesmas como personas-cidadãs da república americana." Elas engajaram-se não somente no processo de auto-formação, mas se autorizaram a ter outros também representados como lhes pareciam mais apropriado. "Independência" e "Construção Nacional”, de qualquer modo, não eram processos desconhecidos, o que originava um debate tácito sobre identidade na medida em que embarcavam rumo ao seu futuro6. A Comisión deteve-se em sua encruzilhada crítica, encarregada a realizar um censo pictórico no preciso momento em que a fábrica social estava sendo reconstruída como uma nova república americana. Uma linha do "Museum" de Jorge Luis Borges posta na epígrafe evoca perfeitamente o estado de espírito da Colombia em I850: “....Naquele Império, a Arte da Cartografia atingiu uma tal Perfeição que o Mapa de uma só Província ocupava toda uma Cidade, e o Mapa do Império, toda uma Província." Mapas e registros visuais, em outras palavras, carregam um grande peso. Reconfigurar as novas províncias da república e as pessoas nos confins miniaturizados dos mapas e das imagens era criar um documento significativo. $O$ álbum da Comisión foi o produto de uma luta pelo poder interpretativo: entre a metrópole de Bogotá e as províncias rurais; entre o novo governo oficial e sua população descentralizada; entre forças nativas e estrangeiras; entre aspirações coloniais e republicanas.

As relações espaciais da Colômbia são complexas, dada esta característica singular de possuir tanto a costa marítima do Atlântico (ou do Caribe) e a do Pacífico, estando Bogotá situada nas montanhas do interior do país: o terceiro ponto do triângulo territorial. Um mapa das rotas cobertas pela expedição ao longo de seus dez anos 
revela um padrão de borboleta no reconhecimento necessário para atravessar este terreno: espraiou-se a partir da capital e terminou no insalubre Oriente (províncias do leste) onde Codazzi encontrou a morte. O terreno da Colômbia não se conforma com a oposição binária de seus vizinhos, Venezuela e Peru, onde a localização costeira de Caracas e Lima significava a civilização, enquanto que as montanhas isoladas simbolizavam a barbárie. A falta do que nós poderíamos chamar de hierarquia topográfica compõe o dilema ideológico que preocupou a classe dominante, a qual estava insegura sobre como compreender as populações e terras sobre as quais eles pretendiam mandar.

Codazzi e seu grupo expedicionário esperavam resolver esse problema. Mas o que os meios e as tradições artísticas e intelectuais significavam nesse intento de cumprir a tarefa? Seu encargo específico em conduzir uma comissão corográfica é crucial e, além disso, refinou sua concepção das inter-relações da geografia e da corografia, dos mapas e das imagens. A primeira tarefa da geografia é estabelecer as fronteiras físicas ou as fronteiras políticas de massas de terra significantes; este determinado expediente é matemático ou abstrato. Este procedimento fixa essencialmente as relações geométricas e espaciais existentes entre unidades políticas designadas, arranjadas de modo linear sobre uma superfície bidimensional. A corografia, ao contrário, é um modo perceptual. Ela requer um artista para criar um retrato vivo da fisionomia distinta da paisagem diversamente habitada, individualmente discreta e seqüencialmente adjacente das mini-regiões. A Comisíon utilizou estes sistemas competitivos de representação, projetando-os dentro de uma série de lugares em volta do país, o que contribuiu para a formulação de uma narrativa nacional.

A solução da Comisión foi brilhante: insistiu em tomar os novos departamentos como a unidade organizacional e ligar a fisionomia regional e os trajes com ambientes naturais característicos. Este determinismo do meio ambiente proveu a fundação de todo o empreendimento. A mensagem a qual grupos de pessoas (ou subgrupos raciais) compartilham características moldadas por sua topografia local foi visualmente codificada no álbum. Ele informava as figuras individuais que enfatizavam a interdependência homem/natureza (e presumivelmente poderia ter informado também a seqüência de estudos de figuras intercalada com paisagens puras, ainda que Codazzi tenha morrido antes que pudesse supervisionar a publicação do álbum). Esta prática tornou-se padrão nos relatos de expedição ao longo do século dezenove. É preciso que nos lembremos, entretanto, que no início da Comisión, a Colômbia era uma nação independente há apenas vinte e cinco anos. Mais de três séculos de mando espanhol deixaram marcas artísticas de duas maneiras que são imediatamente significativas para nós. Primeiramente, seu legado colonial mal permitiu um gênero distinto de paisagem. Em segundo lugar, a arte figurativa espanhola do século dezenove foi largamente devotada aos temas religiosos, com a arte secular apenas começando a emergir. Por essa razão, necessitamos examinar a dupla pictórica de homem e natureza que caracteriza a Comisión como uma acomodação entre a instrução de Codazzi e a herança artística colonial. 


\section{Entre costumbrista e pintura de casta}

O Fazendeiro Mestiço (Mestizo Farmers) de Fernández é uma das poucas imagens da Comisión que nos é familiar por suas aparições nas pesquisas do século vinte. Como outras de suas aquarelas, esta particulariza os trajes dos homens e mulheres, seu tom da pele como marca da raça, detalhes de sua ocupação e os entornos naturais. Cada um representa um híbrido entre um estudo etnográfico e uma pintura de gênero ou cena do dia a dia: um tipo usualmente subsumido sob a categoria de pintura costumbrista. Costumbrista pode ser definida de modo geral como a arte de estereótipos visuais, retratos de pessoas nativas por artistas viajantes estrangeiros interessados no estabelecimento de tipos abrangentes - normalmente, nacionais. Sob Codazzi, Fernández desenvolveu uma leitura nuançada da população que mais realçou do que suprimiu as diferenças regionais encontradas nas províncias de Tunja, Tundama, Ocaña, Socorro, Soto e Vélez. Um cuidadoso escrutínio da fisionomia, dos trajes e ocupações foi sobreposto acima da terra, à maneira de um mapa de relevo estendido sobre as fronteiras nacionais. Ao lado da identificação com regiões, entretanto, a Comisión respondeu à necessidade de classificar a população de acordo com a classe, o que, no período colonial havia sido definida em parte pela raça. Então, as figuras no álbum são marcadas em uma ordem social descendente tais como Notables, Personajes, Tipos, Campesinos, Napangas e Indios (Compare-se Tipos de Medellín, de Price e seu Personajes de Medellín, revelando sua intenção de diferenciar classe entre pessoas da mesma região).

Este impulso para a identificação racial e de classe teve antecedentes pictóricos na pintura de Casta, a qual representou uma das poucas formas de arte estritamente seculares no período colonial. Elas proporcionaram uma janela singular dentro da vida e da sociedade colonial, produzida sobretudo no México, Peru e Equador (o qual esteve anteriormente unido com a Colômbia) e um testemunho visual da heterogeneidade cultural e da mistura racial que permeava a vida das colônias espanholas na América. Foram criadas de forma usual como uma série de dezesseis telas, ainda que ocasionalmente as cenas sejam representadas em uma superfície singular e compartimentada. Elas ilustram os resultados da mistura de três grupos raciais majoritários que formaram a população do Novo Mundo nos tempos coloniais - indígenas, espanhóis e escravos africanos - cada uma delas com cenas retratando tipicamente um homem e uma mulher de diferentes raças com um ou dois membros da prole. Elas eram acompanhadas por um texto que identificava precisamente a mistura racial representada. Inscrita em uma imagem, por exemplo, está a fórmula: “indígenas e mestiços produzem coyote". Adquirido primeiramente pela elite espanhola, a pintura de Casta preencheu a necessidade de classificação: classificação não somente das misturas raciais, mas também das ocupações, costumes, trajes e modos de vida. Usualmente, as figuras ocupam um ambiente doméstico ou uma paisagem e delineiam objetos emblemáticos que revelam a vida familiar e a posição social. Os estudos de 
figuras da Comisión, em minha leitura, são um amálgama desta tradição de casta, enxertada dentro de um formato costumbrista. É essa herança pictórica misturada que provê os meios de retratar a sociedade colombiana, inscrevendo a classe racial e sócio-econômica dos retratados.

\section{Uma Iconografia para a classe média de Medellín}

Trabalhando para a Comisión em I852, Price proporcionou uma visão amplificada da Cordilheira Central, com seu centro movimentado em Medellín. Seu Río Negro (fig. 3) coloca, de pé, um casal de ascendência branca - crioulos - ante uma clareira em declive. A mulher está posicionada vários passos atrás de seu marido, submetendo-se à sua posição dominante; eles vestem um rústico traje fora de moda que identificam seu status econômico médio. Diferentemente de Notáveis da Capital, Santander, de Fernandez, esta não é a representação de um lazer elegante ou dos privilégios de algum endinheirado; nem está de acordo com a visão que Paz tem dos trabalhadores da classe média. Ao contrário, nós temos a sensação que Price interrompeu essa gente na administração diária de sua modesta propriedade rural e os convenceu a tirar um retrato em frente a sua casa. Típico de sua posição, eles buscam uma auto-apresentação adequada, ficando eretos e fixando a vista acima da montanha, sobrepujados pela entrada de sua modesta hacienda.

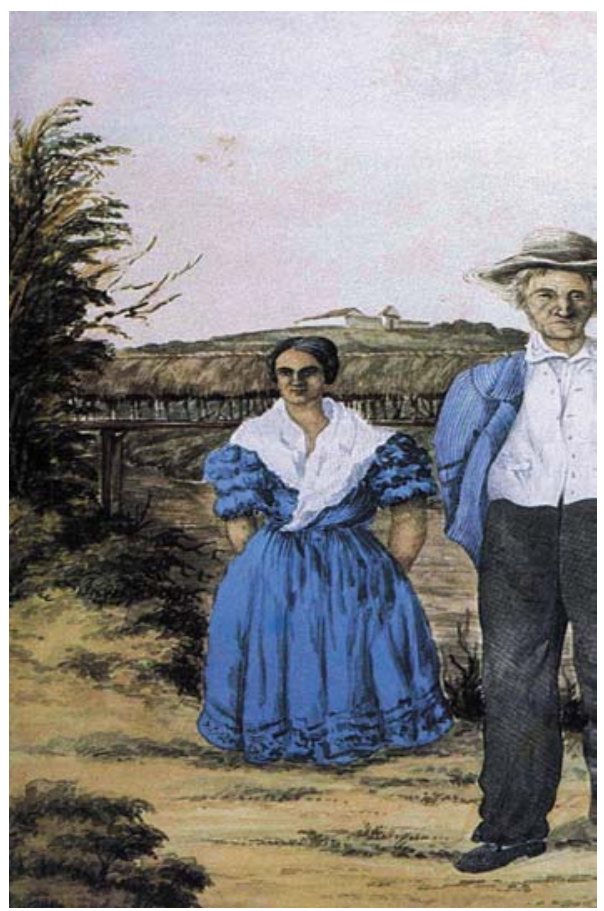

Como podemos dar conta disto que apenas pode ser descrito como a aparência de um casal burguês do campo, nessa imagem de Price, em um momento na história da Colômbia em que freqüentemente é alegado que não existe uma classe média? Qual a base lógica para visualmente mapear essas fronteiras, pela parte do artista e de Codazzi e seus patrões? Esses trabalhos foram feitos em Antioquia, que era um raro caso não somente na Colômbia, mas em qualquer lugar na América Latina, de uma fronteira dinâmica produzindo uma classe média rural. Como o historiador Alistair Hennessy anota:

Fig. 3 - Henry Price, Río Negro, 1852. Biblioteca Nacional, Bogotá, Colombia. 
Alistair Hennessy, The Frontier in Latin American History. Albuquerque: University of New Mexico Press, 1978, pp.96-97.

Ann Bermingham, Landscape and Ideology: The English Rustic Tradition, 1740-1860. Berkeley: University of California Press, c.1986, p. 30.
A partir dos anos 1830, a fronteira do café foi empurrada para a parte mais ao Sul da Antioquia como conseqüência da iniciativa dos comerciantes de Medellín, cujo propósito de adquirir terra foi encorajado pela migração e povoação... Esta foi uma política de um interesse pessoal ilustrado. Mercadores requeriam uma força de trabalho assentada das quais eles pudessem utilizar para suas aventuras especulativas... Isto não somente facilitou o futuro desenvolvimento de suas propriedades cafeeiras, mas auxiliou a emergência de uma considerável classe de pequenos proprietários que se tornavam criadores de porcos e cultivavam, eles mesmos, o café quando se expandia. ${ }^{7}$

Antioquia testemunhou o nascimento de uma classe média rural - o início do desenvolvimento de um mercado interno - a qual a elite comerciante serviu como parteira. Representativo do interesse comercial britânico na América do Sul, a celebração deste casal de Price - cheio de orgulho burguês - deve ser entendido nesse contexto.

Enquanto esta figura está há um oceano de distância e um século mais tarde do retrato de Mr. And Mrs. Robert Andrews, do compatriota de Price, Thomas Gainsborough, há aí uma espécie de afinidade de aparência e intenção. Ambos apresentam um marido e mulher em uma paisagem cultivada, trabalhadores rurais ou algo assim; e ainda, ambos expungem os trabalhadores que obviamente aravam a terra. Como Ann Bermingham notou sobre o tempo de Gainsborough:

\section{Em geral, o período fez um acréscimo na rígida distinção entre paisagem como o domínio natural de um senhor de terras e cenas agrárias como a província apropriada ao trabalhador. ${ }^{8}$}

A Colômbia que Price encontrou em 1852 fez face a um dilema não diferente ao do capitalismo agrário começando lentamente a substituir a fazenda de subsistência, nessa região especialmente. $O$ artista trabalhou no sentido de correspondências formais que ligavam o homem e a natureza; a posição cerimoniosa do homem reverbera na infrutífera planta aprumada à direita, enquanto que a forma arredondada da mulher - com a saia campanular e as mangas bufantes - é repetida na vegetação mais cheia e frondosa, ao seu lado na figura. Então, enquanto estas pistas visuais apontam para a identidade própria entre proprietário e propriedade, há também o fato óbvio que eles estão em um contato mínimo com a terra, ou um com o outro, Price retrata uma inquietante aliança que é, provavelmente, peculiar à região que ele percorre, a este momento histórico e à própria sensibilidade artística, apurada dentro da tradição rústica inglesa. 
Os desafios e possibilidades de uma classe média em desenvolvimento na Colômbia são ainda mais elaborados em Antioquia, quando um casal crioulo toma seu lugar ao lado direito de um friso com figuras representando os estratos sociais e raciais locais. No lado oposto está um homem negro, identificado, por sua blusa branca e pelos pés descobertos, como um camponês; e entre eles, literalmente e figurativamente aparecem duas mestizas, com jarros de água equilibrados em suas cabeças. Uma fonte pitoresca, um amontoado de casas cobertas com telhas e a face de uma igreja os situam dentro da vida da cidade, abrigados contra os picos dos Andes.

\section{A resposta à terra}

Na paisagem, Price também alcançou uma acomodação das convenções do Velho Mundo com as realidades do Novo Mundo. O que o conduz a ser visto como o pai da pintura de paisagem colombiana. E sua Montaña de Sonsón (fig. 4) ele fornece um vislumbre da natureza primeva, antes da expansão do cultivo do café transformar a paisagem. Apresenta-se a densidade da vegetação a qual, com suas folhagens variadas e vinhas, cria um padrão integrado que lança-se insistentemente para a superfície. Este efeito é aumentado por sua palheta monocromática marrom e pelo formato vertical, que arrasta os olhos do espectador ao longo da superfície plana da pintura mais do que dentro de sua profundidade. Os leves tons de sépia acima se abrem ao céu, mas tornam-se mais escuros e densos quanto mais eles se aproximam da base da composição: o que poderia ser entendido como o seu "coração das trevas". Este sentimento de mistério é acentuado pela presença da figura masculina, vestida apenas com um chapéu e calção curto e que se ergue com as costas voltadas ao espectador à beira de seu reino sombrio. Ele é o último em uma procissão de ameríndios, descendo para a mata e desaparecendo de vista, apenas com o cimo de seus chapéus de palha ainda discerníveis. Entre os mais expressivos dos trabalhos de Price, esta imagem pode ser lida como uma metáfora da resistência à exploração, à colonização e mesmo à compreensão. Esta composição fornece uma alternativa à composição panorâmica de salão.

Fig. 4 - Henry Price, Montaña de Sonsón, 1852. Biblioteca Nacional, Bogotá. Colombia.

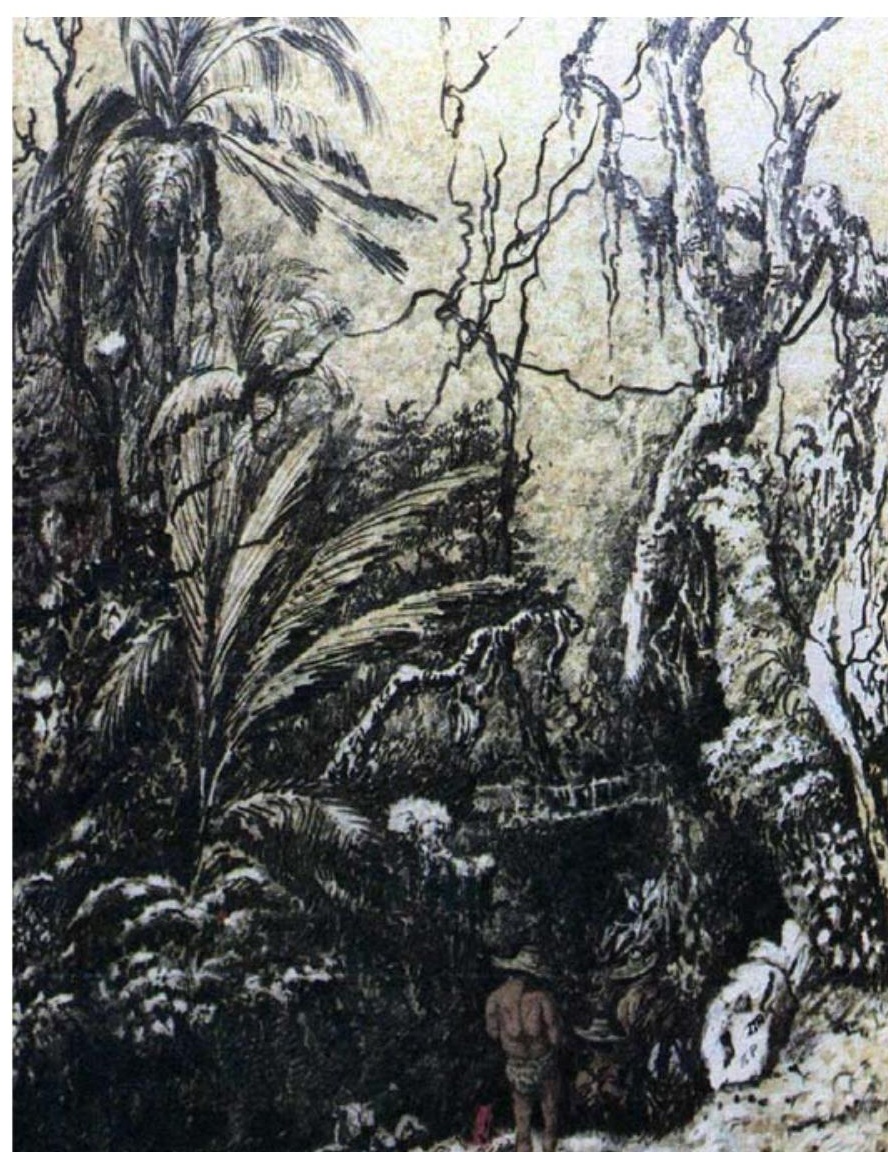


A vegetação da selva - com os picos das montanhas e as erupções vulcânicas pertence ao sublime natural, inspirando medo e admiração terrífica no observador, enquanto que simultaneamente mantém a promessa de segredos a serem revelados. Price joga aqui com essa dualidade; no limiar da direita de Montaña de Sonsón uma seqüência de petróglifos - uma mensagem do passado, inscrita em indecifráveis códigos - aparece em um seixo, cujo lado, por seu turno, sugere uma máscara mortuária ou uma caveira.

A Colômbia em I 850 confrontou-se com um problema não diferente daquele dos Estados Unidos (ainda que em escala menor): o problema da fronteira, do espaço vazio. Na Colômbia dessa época, algo em torno de noventa e oito por cento da população vivia nas montanhas, nas escarpas oestes dos Andes e na costa, enquanto que as áreas do leste - compreendendo metade do país - permaneciam praticamente desabitadas. O gado bravio impulsionou a população para Casanare e os llanos da Colômbia. Por outro lado, permanecia a selva indomada do trabalho literário de Rivera "La Voragine”. As províncias cobertas por Paz - Mariquita, Neiva, Casanare, Popayán, Pasto, Túquerres, Buensaventura, Chocó, Barbacoas e Caquetá - incluíam tal território. Esses espaços vazios impuseram um duplo dilema: como faria o governo para efetivar a redistribuição da população e como faria o artista para retratar estes lugares inabitados e em sua maior parte inabitáveis? Os artistas Paz, Fernández e Price - trabalhando com Codazzi diariamente - absorveram sua orientação geográfica e suas estratégias para mapear o terreno da Colômbia. Isto foi particularmente verdadeiro no caso de $\mathrm{Paz}$, que passou sete anos pesquisando sua terra natal lado a lado com Codazzi. Essa experiência o encorajou a mesclar dados empíricos, coletados in loco, com as convenções artísticas de sua herança colonial. Desse modo ele foi capaz de forjar uma variedade de configurações da paisagem que em efeito misturaram o ideal e o real. Isto é revelado em dois formatos de paisagens distintos: os panoramas que estendem largas fatias de terreno diante do espectador e os estudos pormenorizados da natureza, que providenciaram a oportunidade de um escrutínio detalhado de plantas, árvores ou formações rochosas.

\section{Paz e a auto-etnografia}

Codazzi morreu em 1859 no Oriente. Mas como o resto do grupo da expedição, nós atravessamos o país apenas para retornar a Bogotá, onde os mapas, cartas, textos e imagens pictóricas foram submetidos. Mas sem a condução de Codazzi, eles definharam sem planos próprios para sua futura exposição ao público. Se ele tivesse vivido para ver o material da expedição publicado, então, como eles teriam sido apresentados? Podemos imaginar a tomada dos mapas criados por Codazzi e o esboço das coordenadas onde a expedição parou, e os artistas criando suas aquarelas. Pontos selecionados no mapa bidimensional, em outras palavras, onde se erguiam em representações tridimensionais 
da topografia e dos habitantes. Junto, os dois sistemas de geografia e corografia teriam provido uma figura complexa e com múltiplas camadas, pela qual a nação poderia ter compreendido a si mesma e seus recursos materiais e sociais.

A realidade não foi tão ambiciosa. Em 1862 foi publicado um estudo escrito intitulado Geografia dos Estados Unidos da Colômbia, mas nenhum álbum abrangente das figuras apareceu. Somente em I 889 Paz compilou a pedido do governo O Atlas Geográfico da Colômbia, que destacou os mapas e omitiu as ricas imagens pictóricas. Preencheram essas publicações os objetivos originais de Codazzi e da Comisión? Do presidente Lopez e de seu eleitorado crioulo? Neste breve artigo é impossível analisar estas questões plenamente, mas para nossos propósitos aqui nós pudemos revisitar brevemente os encargos de uma comissão corográfica. A corografia historicamente tem sido uma ferramenta no arsenal do Império, como John Moffitt observou:

\begin{abstract}
É um truísmo dizer que tanto quanto as armas e os navios de guerra, os mapas são ferramentas indispensáveis do imperialismo. Marcando pessoas e regiões no mapa e capturando a terminologia nativa nos manuscritos do conquistador, os espanhóis do século dezesseis cimentaram seu poder colonial através da descrição, classificação, nomeação e então, oportunamente, inventando a ficção de sua "Nova Espanha"... a corografia, com seu distintivo sinal "civilizatório" europeu - cidades, igrejas, fortes, estradas, portos, pomares e cidades - foi o instrumento didático da época pelo qual se transformou, literalmente se domesticou, a selvageria dos bárbaros, do "Outro", dentro do simulacro da Pax europea. ${ }^{9}$
\end{abstract}

A Comisión Corográfica forneceu uma variação desse tema. Não mais um instrumento nas mãos de conquistadores estrangeiros, a corografia tornou-se o instrumento do governo de Lopez na Colômbia pós-independente, um meio de imposição da ordem visual sobre a sublevação política e social que partia no caminho da revolução. Nessas páginas a população provinciana foi descrita, classificada e posicionada dentro da ordem social em expansão que definiu a nova Colômbia e sua classe governante crioula.

É apropriado concluir com o trabalho de Paz, com o qual começamos. Pouco discutido aqui é que a arte da Comisión tem escalado Paz como um talento menor e como um dedicado trabalhador. A posição de Paz, no entanto, como um nativo dentro da Comisión e um artista local deve nos impelir a reconhecer o valor de seu trabalho no contexto daquilo que Pratt chamou de um documento auto-etnográfico: ou seja, como aquele "Outro" que é construído em resposta a, ou em diálogo com, as representações metropolitanas. As imagens auto-etnográficas são, por essa razão, não autênticas formas

(1)


de auto-representação, mas envolvem a colaboração parcial com, e apropriação dos, idiomas do conquistador. Consideremos, por exemplo, a representação de Paz de um casal de sua cidade natal de Cauca (fig. 5) que tipifica seus empréstimos da arte viajante e acadêmica, hibridizada com modos indígenas. Comparações desse trabalho com a representação de Price dos habitantes de Río Negro (fig. 3, acima) ajuda-nos a distinguir a abordagem de Paz. O casal de Price aparece lado a lado, mas não mantém um contato físico; mesmo suas cabeças e olhares voltam-se em direções diferentes. A combinação de cores do vestido azul da mulher e da jaqueta azul do homem os une visualmente enquanto que seu lugar no campo pictórico - preenchendo a maior parte da extensão horizontal da aquarela - estabelece seu domínio sobre a paisagem. Essas pessoas são proprietários de sua terra, mas não se sentem especialmente confortáveis em seu status econômico médio. A designação de Paz para a mulher em sua aquarela como ñapanga é significativa por ser esse um termo de origem quéchua que significa mestiça ou mulata da classe média. Seu uso desse termo em relação à população de Cauca é eloqüente, porque especifica sua situação não apenas racial, mas também cultural. Ela é mostrada descalça, vestida com uma saia simples, blusa e sem nenhum xale em sua cabeça. Ela se mantém com seu braço com o do seu cônjuge, o qual é identificado como um mestiço. Eles estão contra um muro ou cerca com vegetação e uma paisagem montanhosa atrás, e aparecem confortavelmente contra a vista panorâmica de Cauca. Como podemos ver nessa comparação, ela segue a fórmula geral usada por Price para a imagem do marido e da mulher brancos na paisagem, mas parte disso para sugerir as circunstâncias culturais diferentes deste casal multirracial. Eles parecem estar mais confortáveis em seu meio-ambiente e simultaneamente menos ligados a propriedade. É útil também pensar nesse e em outro trabalho de Paz como dialógico, bilíngüe e, portanto capaz de dirigir-se a audiências tanto na capital quanto nas províncias. Outros estudos podem de fato revelar as imagens de Paz como as mais importantes como ponto de entrada para a população regional dentro da cultura visual metropolitana.

Um duplo cartográfico é o objetivo desse álbum. Essa dualidade replica o dilema das repúblicas do

Fig. 5 - Manuel María Paz, Napanga y mestizo del Cauca, 1853. Biblioteca Nacional, Bogotá, Colombia. 
Novo Mundo: a realidade da mestiçagem, a conjunção de oposições étnicas, como aqui onde o casal é identificado com o título de "Ñapanga y mestizo". O objetivo dos crioulos da Colômbia é e foi ganhar a independência da Espanha enquanto mantinham a sofisticação da Europa e a supremacia branca. Mesmo que em volta deles uma nova raça mestiça estivesse em formação e ascensão. A paisagem foi o palco onde se deu o combate. O álbum da Comisión forneceu uma construção visual retratando o meioambiente nativo no qual a nova raça tomou forma. Este é um raro fóssil sobrevivente do início da era independente, um notável auto-retrato.

\section{$\Gamma$}

KATHERINE MANTHORNE é professora de Arte Moderna das Américas no programa de História da Arte da Universidade de Nova lorque. Antes disso, liderou o centro de pesquisa do Smithsonian American Art Museum. Entre seus trabalhos, Tropical Renaissance. North American Artists Exploring Latin America, 1839 -1879 transformou-se num livro de referência; seu mais recente trabalho intitula-se Pictured Women Narrate their Histories: The Art \& Culture of Reconstruction, 1863-1877. É membro do Conselho Consultivo para o Museo Del Barrio e foi eleita para o Conselho de Diretores do College Art Association (2006-2010). 